Portland State University

PDXScholar

Environmental Science and Management

Faculty Publications and Presentations

$12-1-2014$

\title{
Damage and Alteration of Mangroves Inhabited by a Marine Wood-Borer
}

Timothy Mathias Davidson

Smithsonian Tropical Research Institute

Catherine E. de Rivera

Portland State University, derivera@pdx.edu

Hwey-Lian Hsieh

Biodiversity Research Center

Follow this and additional works at: https://pdxscholar.library.pdx.edu/esm_fac

Part of the Environmental Sciences Commons

Let us know how access to this document benefits you.

\section{Citation Details}

Davidson, T. M., de Rivera, C. E., \& Hsieh, H. L. (2014). Damage and alteration of mangroves inhabited by a marine wood-borer. Marine Ecology Progress Series, 516, 177-185.

This Article is brought to you for free and open access. It has been accepted for inclusion in Environmental Science and Management Faculty Publications and Presentations by an authorized administrator of PDXScholar. Please contact us if we can make this document more accessible: pdxscholar@pdx.edu. 


\begin{tabular}{c|c|c}
\hline \hline $\begin{array}{c}\text { Vol. 516: 177-185, 2014 } \\
\text { doi: } 10.3354 / \mathrm{meps} 11046\end{array}$ & $\begin{array}{c}\text { MARINE ECOLOGY PROGRESS SERIES } \\
\text { Mar Ecol Prog Ser }\end{array}$ & Published December 3 \\
\hline \hline
\end{tabular}

\title{
Damage and alteration of mangroves inhabited by a marine wood-borer
}

\author{
Timothy M. Davidson ${ }^{1,3, *}$, Catherine E. de Rivera ${ }^{1}$, Hwey-Lian Hsieh ${ }^{2}$ \\ ${ }^{1}$ Department of Environmental Science and Management, Portland State University, PO Box 751, Portland, OR 97207, USA \\ ${ }^{2}$ Biodiversity Research Center, Academia Sinica, Nankang, Taipei, Taiwan 115, ROC
}

${ }^{3}$ Present address: Smithsonian Tropical Research Institute, Apartado Postal 0843-03092, Balboa, Ancon, República de Panamá

\begin{abstract}
Animals can exert a strong influence on the structure and function of foundation species such as mangroves. Because mangroves live at the interface of land and sea, both terrestrial and marine species affect them, including numerous herbivores and boring species. These organisms can affect the fecundity, performance, and morphology of mangroves. In a mangrove stand in southwestern Taiwan, we discovered that mangroves were extensively damaged by woodboring isopods Sphaeroma terebrans. We examined the relationships between burrowing damage from $S$. terebrans and metrics of mangrove fecundity, performance, and morphology. Individuals of Rhizophora stylosa that were more burrowed by isopods had significantly fewer propagules, fewer ground roots stabilizing the tree, smaller leaves, and more non-foliated twigs. Similarly, Avicennia marina with more burrows had fewer pneumatophores and lenticels (used for gaseous exchange), and pneumatophores with more necrotic tissue. The most heavily damaged trees were hollowed-out with burrows (A. marina) or fell over when their supportive root system failed $(R$. stylosa). These correlations suggest that marine wood-borers can negatively influence mangroves and alter tree morphology, although other stressors may also be involved. While studies have examined the effects of isopods on root-level production, we provide the first quantitative evidence that localized burrowing damage is correlated with tree-level effects. These results are consistent with other literature demonstrating the importance of sub-lethal damage by borers in shaping foundation species. Such damage may have cascading effects on the diverse assemblages of marine and terrestrial biota that use mangroves as habitat.
\end{abstract}

KEY WORDS: Habitat alteration $\cdot$ Mangrove $\cdot$ Plant-animal interactions $\cdot$ Sphaeroma terebrans Sub-lethal stress

Resale or republication not permitted without written consent of the publisher

\section{INTRODUCTION}

Animals can strongly affect the morphology and structure of habitat-forming foundation species and the habitats they comprise (Mopper et al. 1991). For example, animals alter mangrove trees through folivory, wood-boring, and feeding on propagules (Ellison \& Farnsworth 1990, Feller 2002, Sousa et al. 2003, Cannicci et al. 2008). Insects have substantial negative effects on mangrove trees causing dramatic and widespread alterations of growth and survivor- ship (Piyakarnchana 1981, Whitten \& Damanik 1986, Anderson \& Lee 1995). However, marine wood-boring isopods may also be important structuring agents in mangrove ecosystems. Several studies have linked the prodigious boring by high densities of sphaeromatid isopods to the loss of mangroves in Florida (Rehm \& Humm 1973, Rehm 1976), Kenya and Tanzania (Svavarsson et al. 2002), and India (Santhakumari 1991).

Isopod burrowing or boring (used synonymously herein) changes the morphology and integrity of 
mangrove roots, which can have mechanical and physiological consequences. The aerial roots of red mangroves buttress and anchor the tree; the destruction of aerial roots by isopods has been suggested to increase the susceptibility of mangroves to damage from storms (Rehm \& Humm 1973, Santhakumari 1991). While burrowing by sphaeromatid isopods can initiate root branching (Simberloff et al. 1978, Perry \& Brusca 1989), these sub-lethal burrowing effects cause a net reduction in root growth and productivity (Perry \& Brusca 1989, Brooks \& Bell 2002) and divert resources from production to repair (Brooks \& Bell 2002). Roots are also important for gaseous exchange and nutrient absorption, and they are photosynthetic (Gill \& Tomlinson 1977, Tomlinson 1986, Kitaya et al. 2002). Because borer damage diverts resources from the generation of propagules, leaves, and other structures to repair, we hypothesize that high levels of isopod boring may affect unbored parts of the tree. However, most relevant studies are anecdotal or focus on isopod interactions at the root level (Rehm \& Humm 1973, Perry \& Brusca 1989, Santhakumari 1991, Brooks \& Bell 2002); no studies have previously quantified how isopod effects may scale up to alter and damage structures other than roots.

The tropical and subtropical isopod Sphaeroma terebrans is a prevalent borer in mangrove trees in brackish areas of Australia, Africa, the Caribbean, and Asia (Kensley \& Schotte 1989, T. M. Davidson unpubl. surveys). Sphaeromatid isopods are filter feeders that create burrows for habitat and are often found in the intertidal mangrove fringe. During surveys of a mangrove stand in southwestern Taiwan, we discovered that $S$. terebrans had extensively bored into the mangroves Rhizophora stylosa and Avicennia marina. The most heavily burrowed trees appeared unhealthy, exhibiting low leaf cover, small leaves, and few grounded aerial roots ( $R$. stylosa) and few intact pneumatophores (A. marina) compared to lightly burrowed trees. Hence, we examined how isopod boring was associated with tree-level metrics of morphology, performance (factors that affect survivorship or growth, such as leaf size, tree height, etc.), and fecundity of these 2 mangrove species. We hypothesized that trees with more burrow damage would be smaller in size, have smaller leaves, and have fewer and altered root structures. We also expected additional expressions of damage that vary between these trees due to their different morphologies (e.g. $R$. stylosa: percentage of broken aerial roots, number of grounded roots; A. marina: pneumatophore density, percent cover of necrotic tissue).

\section{MATERIALS AND METHODS}

\author{
Study site
}

We examined the relationships between boring damage by Sphaeroma terebrans and the morphology and performance of mangrove trees in Haomeiliao Nature Preserve (Chiayi County, Taiwan; $23^{\circ} 21.661^{\prime} \mathrm{N}, 120^{\circ} 07.826^{\prime} \mathrm{E}$ ) in July 2010 . Haomeiliao Nature Preserve comprises a gradually sloping intertidal mangrove stand with a muddy-sand substratum in a semi-enclosed lagoon in southwestern Taiwan. The upland border of the stand is primarily composed of Australian pine Casuarina sp. and few individuals of Hibiscus tiliaceus. The upland transitions to an expansive stand of small Avicennia marina ( 1-2 $\mathrm{m}$ tall) and then to a mixed low intertidal zone with small A. marina, some Rhizophora stylosa ( 2-3 $\mathrm{m}$ tall), and scattered Kandelia obovata near the stand edge. This seaward edge is relatively open and has numerous gaps (Fig. S1 in the Supplement at www.int-res.com/articles/suppl/m516p177_supp. pdf). Further seaward are scattered patches of the seagrass Halophila beccarii. To augment the existing population of A. marina, several thousand propagules of R. stylosa and Lumnitzera racemosa (not observed in this study) were planted in 1993-1994 (Peng et al. 1993, Chen et al. 1996), and additional A. marina trees may have been planted in 1975, although records are unclear (M. L. Xue, Taiwan Endemic Species Research Institute, pers. comm.). A. marina trees naturally occurred at the site before restoration began, so their ages may vary. Both undamaged and damaged trees were present throughout the study area. Haomeiliao hosts the northernmost population of $R$. stylosa in Taiwan (Hsueh \& Lee 2000), while the range of $A$. marina extends $\sim 150 \mathrm{~km}$ north to Hsinchu (T. M. Davidson pers. obs.). Natural recruitment of $R$. stylosa, A. marina, and some $K$. obovata was apparent throughout the stand and along the mangrove shoreline. Salinity, air temperature, and sediment temperature were $29.7 \pm 3.0 \mathrm{PSU}$, $29.3 \pm 1.2^{\circ} \mathrm{C}$, and $31.4 \pm 0.7^{\circ} \mathrm{C}($ mean $\pm 95 \% \mathrm{CI}$ ), respectively, during the study period. Haomeiliao experiences mixed semi-diurnal tides (tidal range is 96-206 cm in July).

\section{Shoreline sampling of mangrove and abiotic factors}

We sampled 13 A. marina trees and $10 R$. stylosa trees accessible along a $\sim 600 \mathrm{~m}$ transect placed 
roughly parallel to the seaward edge of the mangrove stand. Due to the inaccessibility of mangroves on the terrestrial side, sampling occurred $11.6 \pm$ $4.2 \mathrm{~m}$ (mean $\pm 95 \% \mathrm{CI}$ ) in from the seaward edge of the mangrove stand. We used random numbers to select the sampling locations along the transect. At each of those locations, we sampled the nearest mangrove tree orthogonal to and shoreward of the transect. Because the mangrove edge was sinuous, trees were sampled at varying distances from the transect but at similar tidal heights (Table S1 in the Supplement at www.int-res.com/articles/suppl/m516p177_ supp.pdf).

The 2 species of mangroves differed in morphology, thus we sampled slightly different tree-level effects and different numbers of roots of each species to test our hypotheses. $R$. stylosa has aerial roots that grow down from the tree to form a flying buttress. In contrast, A. marina exhibits a morphology similar to terrestrial trees (single trunk, broad crown) but is surrounded by numerous pencil-sized pneumatophores (breathing roots) (Tomlinson 1986).

For each tree of $R$. stylosa, we measured how 2 metrics of isopod damage, the percentage of aerial roots burrowed and mean number of burrows per $\mathrm{cm}$ of aerial root, were associated with tree-level effects, including the number of grounded aerial roots and the percentage of broken roots, the number of propagules per tree, tree height, the percentage of first-order branches without leaves (hereinafter: nonfoliated twigs), and mean leaf area $\left(\mathrm{cm}^{2}\right)$. We considered the latter 3 measurements as indicators of performance in $R$. stylosa because those factors could affect or indicate growth and survivorship. For each tree, we counted the number of broken, burrowed, free-hanging, and grounded aerial roots present. We also haphazardly collected 5 free-hanging unbranched aerial root tips by cutting the aerial root tips off at their initiation point (when it was accessible) or approximately $5 \mathrm{~cm}$ above the burrowed area of the root (near the high tide mark on the root). The roots were then dissected in the laboratory to determine the number of isopods per root.

On each tree of $A$. marina, we examined if the total number of burrows per tree was associated with tree height, percentage of broken pneumatophores, pneumatophore length and weight, pneumatophore density and mass, lenticel density, and mean leaf size $\left(\mathrm{cm}^{2}\right)$. Because these factors could affect or indicate survivorship and growth, we consider these factors to be metrics of performance in A. marina; however, many of these factors (e.g. pneumatophore size and density) are also metrics of morphology. We also examined how the mean numbers of burrows per $\mathrm{cm}$ of pneumatophore were related to pneumatophore length and weight, percent cover of necrotic tissue on pneumatophores, and the number of lenticels per pneumatophore. At each sampled tree, we counted the numbers of burrows present, and assessed tree height and the characteristics of the pneumatophores. We randomly collected 10 pneumatophores (pencil-sized roots) from each of $13 \mathrm{~A}$. marina trees by cutting the pneumatophores off at the surface of the sediment at random distances (within $1 \mathrm{~m}$ ) and directions from the bole of the tree. We measured the weight and length, counted the number of lenticels, isopods, and burrows, and visually estimated the percent cover of necrotic or damaged tissue on each pneumatophore. In addition, to measure the density of unburrowed, burrowed, or broken pneumatophores, we randomly placed 3 quadrats $(25 \times 25 \mathrm{~cm})$ within $1 \mathrm{~m}$ of each A. marina tree. We characterized pneumatophores as broken if their tips were missing or hollowed out. The mean mass of pneumatophores per quadrat was estimated by multiplying pneumatophore density by the mean weight of the 10 sampled pneumatophores. Similarly, we calculated the mean density of lenticels per quadrat by multiplying the mean number of lenticels per sampled pneumatophore by the mean number of pneumatophores in the quadrats around the trees. Fecundity could not be assessed for A. marina because propagules were not present at the time of sampling.

Approximately 20 leaves per tree of both species of mangrove were haphazardly collected (without looking) then digitally scanned. The leaf area $\left(\mathrm{cm}^{2}\right)$, percent herbivore damage per leaf, such as discoloration and holes, and percentage of leaves damaged were measured using digital image analysis software (ImageJ, version 1.46r) with a calibrated scale bar. The latter 2 metrics were used to assess the level of leaf herbivory on the trees.

To determine if other factors could be responsible for the inter-tree variation in structure and performance, we measured several other biotic and environmental variables. We examined trees for the presence of other boring organisms (insects, pholads, shipworms, etc.) and conspicuous pathogens (galls, cankers, etc.; Wier et al. 2000). We also measured the potential environmental covariates of tree performance and isopod prevalence including salinity, air and sediment temperature, distance from the seaward edge of the mangrove stand, and relative tidal height. We estimated relative tidal height by comparing the height of the high tide mark on the bole of sampled trees and by using PVC poles coated with a 
marker composed of water-soluble glue and crystal violet stain (dissolvable when tide water contacts it) and placed adjacent to some trees.

\section{Statistical analyses}

We tested the associations between isopod damage and tree morphology, performance, and fecundity using Pearson's correlations. Square-root or log transformations were used to meet the statistical assumptions of Pearson's correlation, reduce the influence of outliers, and improve linearity between variables. We included trendlines and slopes $(b)$ from linear regression to aid in the interpretation of relationships between variables. To account for possible multiple testing issues, we calculated the false discovery rate (FDR) (Benjamini \& Hochberg 1995) and report adjusted p-values ( $(\mathrm{adj}))$ for each family of tests (raw and adjusted $\mathrm{p}$-values are provided in Table S2 in the Supplement). The design included 4 families of tests respective of both metrics of burrowing damage for both mangrove species (Table S2). We set our significance level at 0.05 but also report marginally significant values (between 0.05 and 0.10). We present values as mean $\pm 95 \% \mathrm{CI}$.

\section{RESULTS}

\section{Prevalence, density, and patterns of isopod burrowing damage}

Both Rhizophora stylosa and Avicennia marina trees exhibited extensive burrowing damage from Sphaeroma terebrans (Fig. 1). The most heavily burrowed individuals of $R$. stylosa had discolored leaves, numerous necrotic and broken aerial roots, and few supportive ground roots (some trees had fallen over or were tipping over; Fig. 1b). Approximately $77.1 \%$ of the collected, lab-inspected free-hanging aerial roots (pooled) were burrowed, and $70.8 \%$ harbored isopods. The sampled free-hanging aerial roots had mean burrow densities of $10.3 \pm$ 5.5 per root $(0.7 \pm 0.3$ per $\mathrm{cm}$ of root $)$ and isopod densities of $17.4 \pm 10.2$ per root $(1.3 \pm 0.7$ per $\mathrm{cm}$ of root). The mean number of burrows in roots was strongly positively correlated to the mean number of isopods in roots $\left(\mathrm{r}^{2}=0.89, b=0.511, t=7.92, \mathrm{df}=8\right.$, $\mathrm{p}(\operatorname{adj})<0.001)$.

Isopods were also found in dense aggregations in A. marina. The mean number of burrows in the sampled A. marina trees was $194 \pm 90$ per tree. In contrast to the root-dominated occurrence in $R$. sty-
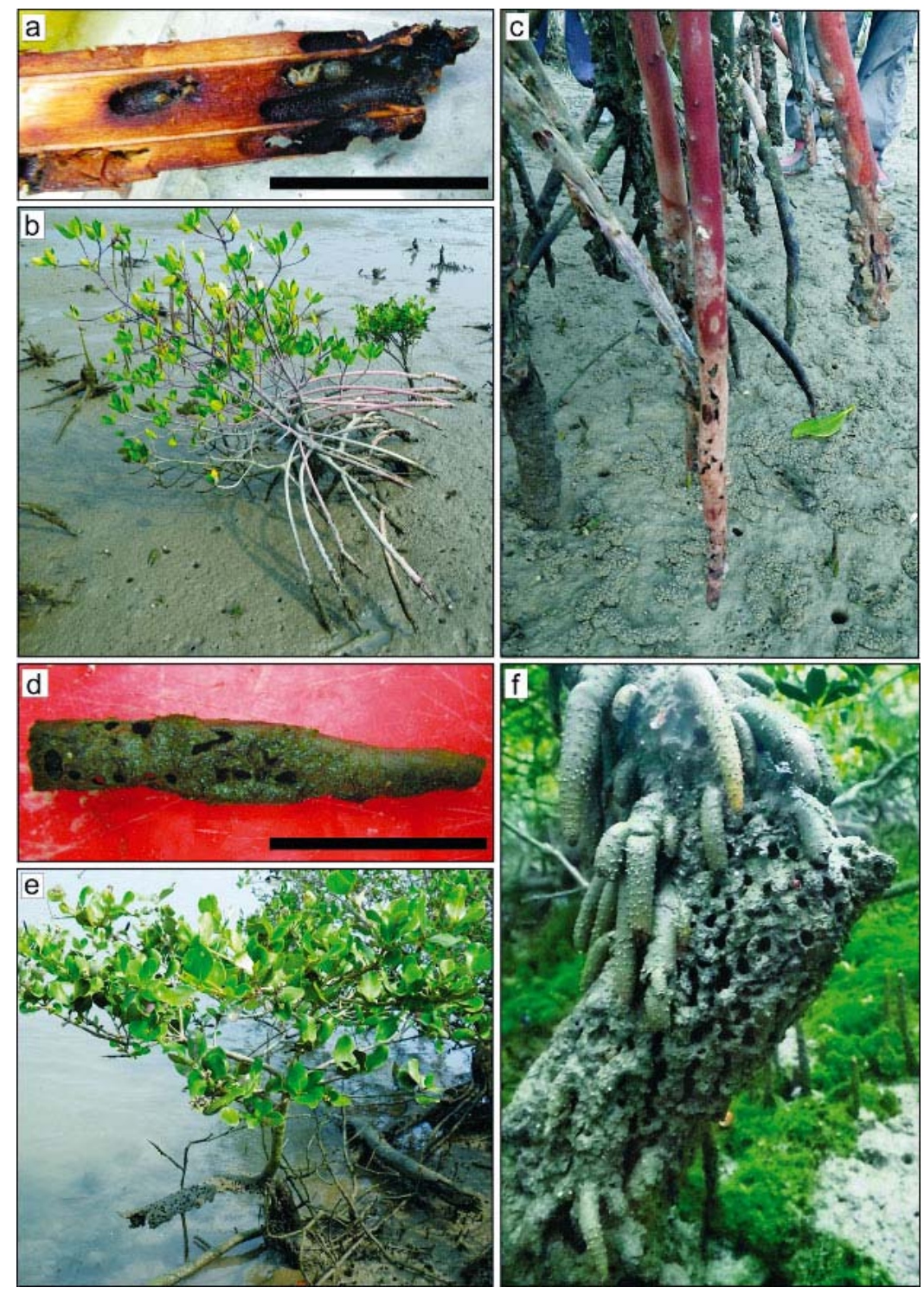

Fig. 1. Prodigious burrowing by Sphaeroma terebrans damaged the mangroves in Haomeiliao Nature Preserve, including $(\mathrm{a}-\mathrm{c})$ the free-hanging aerial roots of Rhizophora stylosa (used to anchor and support the tree), and (d) the pneumatophores (roots used in gaseous exchange) and $(\mathrm{e}, \mathrm{f})$ the trunk and branches of Avicennia marina. Tree height: (b) $\sim 2 \mathrm{~m}$, (e) $\sim 1.5 \mathrm{~m}$. Scale bar: (a) $5 \mathrm{~cm}$, (d) $3 \mathrm{~cm}$ 
losa, more burrows were in the trunk $(53.1 \%)$ and branches $(30.1 \%)$ of $A$. marina than in the exposed areas of roots anchoring the tree in the sediment $(16.8 \%)$. The trees with the most visible damage by burrows had truncated, broken, or necrotic pneumatophores, discolored leaves, and perforated sections or hollowed-out trunks (Fig. 1d-f). Very little force was necessary to break off sections from those damaged trees.

In the collected pneumatophores of $A$. marina, mean burrow and isopod densities were $1.8 \pm 0.5$ and $0.5 \pm 0.2$ per root $(0.4 \pm 0.2$ and $0.1 \pm 0.1$ per $\mathrm{cm}$ of root), respectively. Burrows were present in pneumatophores of all sampled trees and in $65.8 \%$ of all sampled pneumatophores. Isopods were present in pneumatophores of 12 out of 13 sampled trees and in $32.5 \%$ of sampled pneumatophores. Approximately $78.3 \%$ of collected pneumatophores exhibited discolored, necrotic tissue. The tissue had been completely removed in the most heavily burrowed, rotten, and discolored pneumatophores and fell apart when handled.

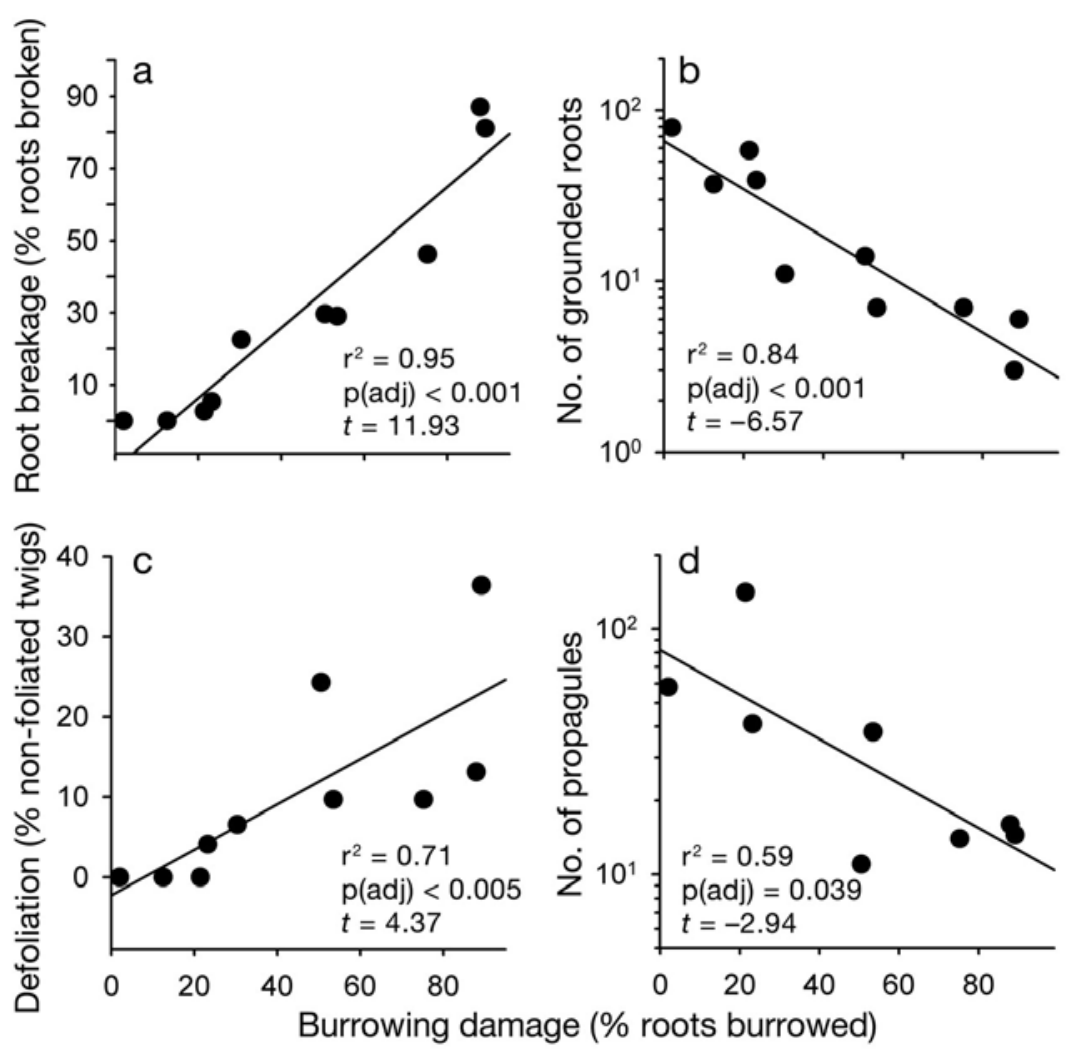

Fig. 2. Relationships between percentage of roots burrowed by Sphaeroma terebrans in Rhizophora stylosa and (a) root breakage, (b) abundance of grounded roots, (c) percentage of non-foliated twigs, and (d) abundance of propagules (all data given 'per tree'). Sample size $(\mathrm{n}=10)$ differed due to missing data on propagules for 2 trees. The $y$-axes of (a) and (c) are back-transformed (from square-root transformations). Note the log-scaling in (b) and (d)

\section{Associations between isopod burrowing and mangrove morphology, performance, and fecundity}

Both measures of isopod burrowing damage (percent of the roots that were burrowed or number of burrows per root) in $R$. stylosa were related to increased root breakage and fewer grounded aerial roots. The percentage of aerial roots burrowed by isopods (as measured in the field) was positively correlated with the percentage of roots that were broken (Fig. 2a) and negatively related with the number of grounded roots present and anchoring the tree in the ground (Fig. 2b). Similarly, the mean number of burrows per $\mathrm{cm}$ in aerial roots was negatively associated with the number of ground roots $\left(\mathrm{r}^{2}=0.44, b=-38.0, t=\right.$ $-2.49, \mathrm{df}=8, \mathrm{p}(\mathrm{adj})=0.084)$ and positively associated with the percentage of broken roots $\left(\mathrm{r}^{2}=0.44\right.$, $b=0.517, t=2.51, \mathrm{df}=8, \mathrm{p}(\mathrm{adj})=0.084)$, although these weak relationships were not significant after FDR corrections were applied (Table S2 in the Supplement at www.int-res.com/ articles/suppl/m516p177_supp.pdf).

More heavily burrowed trees of $R$. stylosa also had fewer twigs bearing leaves and propagules and harbored smaller leaves. The total percentage of roots burrowed by isopods was positively associated with the percentage of non-foliated twigs in $R$. stylosa (Fig. 2c) and negatively associated with the number of propagules (Fig. 2d). Trees of $R$. stylosa with a higher percentage of burrowed roots had significantly smaller leaves $\left(\mathrm{r}^{2}=0.48, b=\right.$ $-15.1, t=-2.53, \mathrm{df}=7, \mathrm{p}(\mathrm{adj})=0.047)$. The mean number of burrows per $\mathrm{cm}$ in aerial roots had a slight positive association with the percentage of non-foliated twigs $\left(\mathrm{r}^{2}=0.41\right.$, $b=0.162, t=2.39, \mathrm{df}=8, \mathrm{p}(\mathrm{adj})=$ 0.084 ) and a slight negative association with leaf size $\left(\mathrm{r}^{2}=0.41, b=-11.4\right.$, $t=-2.23, \mathrm{df}=7, \mathrm{p}(\mathrm{adj})=0.092)$, but these relationships were not significant. We did not detect a significant association between the percentage of roots burrowed by isopods and tree height or between the mean number of burrows per $\mathrm{cm}$ in aerial roots and tree height or the number of propagules on trees $(p(\operatorname{adj})>0.10)$. 

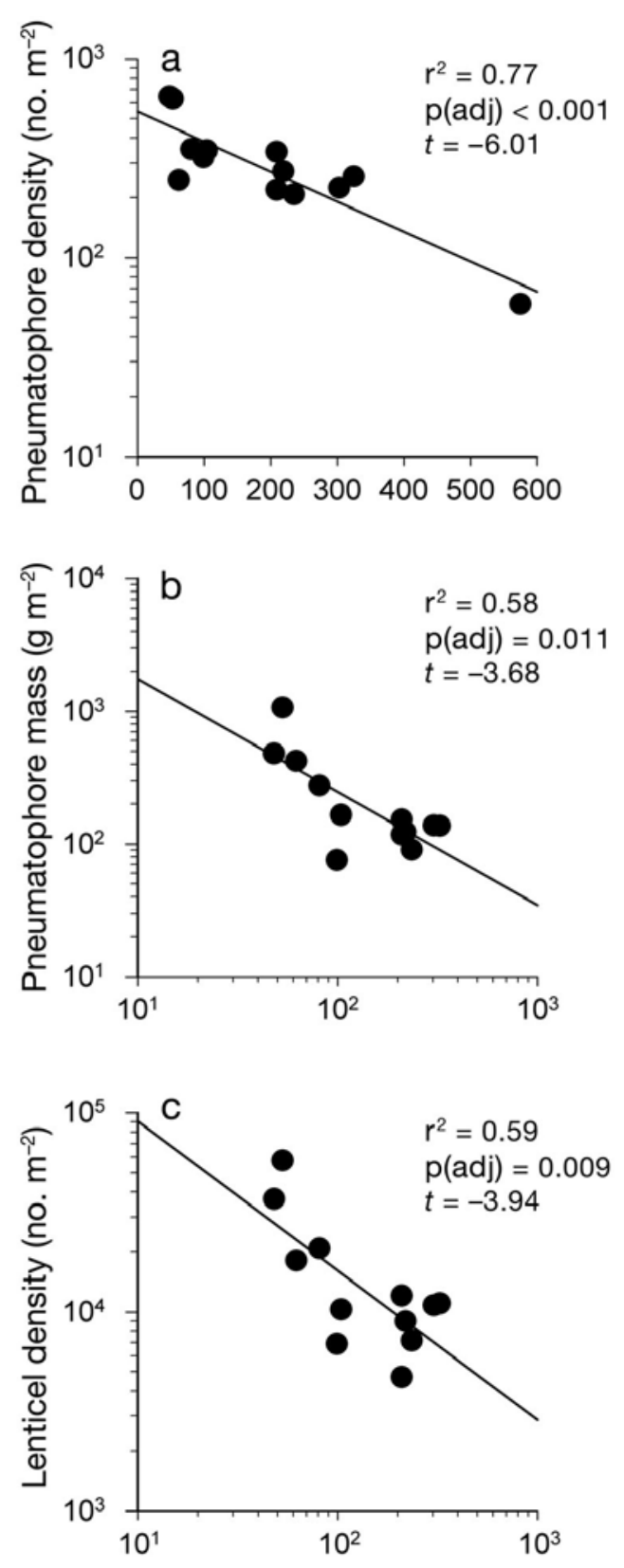

Burrow density (no. per tree)

Fig. 3. Association between number of burrows created by Sphaeroma terebrans per Avicennia marina and (a) mean pneumatophore density, (b) mean mass of pneumatophores, and (c) mean lenticel density. Sample size varied due to a missing sample of pneumatophores for 1 tree needed for estimations of mean mass and lenticel density. Note the log-scaling

In A. marina, more heavily burrowed trees had fewer pneumatophores, a lower mass of pneumatophores, and fewer lenticels. The total number of burrows in A. marina was negatively associated with the mean density of pneumatophores (Fig. 3a). The rela- tionship remained significant even after an influential outlier (from the most heavily burrowed tree in the data collected) was excluded from the analysis $\left(r^{2}=0.47, d f=10, p(a d j)=0.014\right)$. The number of burrows per tree was also negatively associated with the mass of pneumatophores per $\mathrm{m}^{2}$ (Fig. $3 \mathrm{~b}$ ) and mean lenticel density (Fig. 3c), but not pneumatophore length or weight or percent of broken pneumatophores $(\mathrm{p}(\mathrm{adj})>0.10)$. The mean number of burrows per $\mathrm{cm}$ in pneumatophores was positively related to the percentage of pneumatophore surface that was damaged, discolored, and necrotic $\left(\mathrm{r}^{2}=0.75, b=49.1\right.$, $t=5.7, \mathrm{df}=11, \mathrm{p}(\mathrm{adj})<0.001)$, and negatively related to the numbers of lenticels per pneumatophore (although the association was weak and not significant after FDR correction; $\mathrm{r}^{2}=0.37, b=-48.9, t=$ $-2.54, \mathrm{df}=11, \mathrm{p}(\mathrm{adj})=0.054)$. There were no significant associations detected between the numbers of burrows in pneumatophores and the pneumatophore length or weight ( $p(\operatorname{adj})>0.10)$, likely because evidence of burrowing became obscured or removed as the heavily damaged roots further decomposed or broke off. More heavily burrowed trees also had smaller leaves in A. marina $\left(\mathrm{r}^{2}=0.39, b=-0.0053, t=\right.$ $-2.41, \mathrm{df}=9, \mathrm{p}(\mathrm{adj})=0.079)$, although the association was weak and not significant. We did not detect a significant association between the number of burrows per tree and tree height $(p(\operatorname{adj})>0.10)$.

\section{Influences of environmental factors and other organisms}

None of the environmental factors (salinity, air temperature, sediment temperature, distance from the seaward edge of the stand, relative tidal height) explained the variability in the percentage of burrowed aerial roots, numbers of burrows per tree, mean density of burrows per root, or the metrics of tree performance $(\mathrm{p}(\mathrm{adj})>0.10)$. However, a marginally significant negative association was found between the percentage of burrowed roots and the distance from the edge of the stand in $R$. stylosa $\left(\mathrm{r}^{2}=\right.$ $0.52, b=-0.017, t=-2.97, \mathrm{df}=8, \mathrm{p}(\mathrm{adj})=0.072)$, indicating that isopods were present many meters in from the edge. Herbivory (percent cover of leaf damage, percentage of leaves damaged) was not significantly associated with any measurement of burrowing damage, morphology, or performance in either mangrove species $(p(a d j)>0.10)$. No other boring animals (insects, shipworms, etc.) were found in the roots of $R$. stylosa or in A. marina. We did not detect any conspicuous pathogens on trees. 


\section{DISCUSSION}

High levels of isopod boring were related to depressed performance and fecundity and alterations in the morphology of mangrove trees. Previous experiments have quantified the effects of isopod boring on production at the root level (Perry 1988, Ellison \& Farnsworth 1990); however, the present study provides the first quantified evidence that the cumulative effect of localized isopod boring damage can scale up to affect the whole tree. Consistent with our hypotheses, heavily burrowed Rhizophora stylosa had altered root architectures (fewer intact aerial roots to anchor the tree), smaller and fewer leaves, and fewer propagules. Similarly, more burrowed trees of Avicennia marina had smaller leaves and fewer pneumatophores; remaining pneumatophores tended to be more necrotic and damaged than in less burrowed trees.

Trees more affected by isopods could suffer lower performance and survivorship, as photosynthetic capacity, gaseous exchange, and nutrient uptake would cease or be reduced compared to unburrowed trees. The accumulation of minor damage can negatively affect trees by diverting resources to repairing damage (Kulman 1971, Brooks \& Bell 2002) or by causing mortality (Kulman 1971, Ozaki et al. 1999). Many of these trees also exhibited changes in root and canopy architecture related to isopod damage, including fewer supportive aerial roots and smaller and fewer pneumatophores. However, manipulative studies are necessary to definitively assign causality between isopod boring and mangrove damage.

Numerous studies have documented boring sphaeromatid isopod damage in brackish mangroves around the world (Rehm \& Humm 1973, Perry \& Brusca 1989, Santhakumari 1991, Svavarsson et al. 2002), but the extent and intensity of the damage varies among sites. In mangroves experiencing a limited tidal range $(<0.5 \mathrm{~m}$; e.g. Caribbean and Florida), isopod attack is mostly limited to the first few meters of aerial roots of fringing red mangroves that are submerged during high tide (Estevez \& Simon 1975, Simberloff et al. 1978, T. M. Davidson pers. obs.). However, in mangrove sites exhibiting a larger tidal range (e.g. East Africa, Svavarsson et al. 2002; the present study; some sites in Pacific Panama, T. M. Davidson pers. obs.), and in sloping sites with many openings and gaps along the shoreline, isopods can attack trees many meters inside the mangrove stand (Fig. S1 in the Supplement at www.int-res.com/ articles/suppl/m516p177_supp.pdf) because abundant root habitat is available for colonization at high tide. Environmental stressors also affect tree morphology and performance (Tomlinson 1986, Kathiresan \& Bingham 2001) and may exacerbate the effects of borer damage. For example, in our study site, $R$. stylosa and A. marina appear stunted and may be experiencing physiological stresses associated with living near their range edge (Hsueh \& Lee 2000), or they could be stressed by subsidence that has apparently affected the region (Wang 2012). In addition, some of the sampled trees $(R$. stylosa and perhaps $A$. marina) might be the result of a mangrove restoration decades ago, and it is possible that some unknown stressor is affecting these small trees in concert with isopod damage. With respect to such environmental stressors, we do not rule out the possibility that individual trees could vary in their susceptibility to a potential unknown stressor that is correlated with borer damage.

The changes documented in this study in tree architecture (through root alterations), leaf cover, and habitat complexity (through the extirpation of trees) may more broadly affect mangrove and other forest ecosystems as well. For example, alterations in the root structure of mangroves and terrestrial trees alter erosion and sedimentation regimes (Spenceley 1977, Kathiresan 2003, Krauss et al. 2003, Reubens et al. 2007). Herbivory mediates primary productivity (Mattson \& Addy 1975, Feller \& Mathis 1997), alters the distribution of canopy gaps (Feller \& McKee 1999), and changes nutrient flux by facilitating the breakdown and export of plant materials (Lightfoot \& Whitford 1990, Feller 2002, Chapman et al. 2003). Furthermore, the complex structure of mangroves provides important nursery habitats (Primavera 1998, Kathiresan \& Bingham 2001, Nagelkerken et al. 2008); isopod-associated changes could alter the quality and quantity of habitat available to numerous other organisms.

This study suggests that boring marine isopods are important structuring agents of mangroves, although additional manipulative studies are necessary. While the structuring role of herbivory is well documented (Mopper et al. 1991), our study posits that the nonconsumptive boring damage of isopods may also have important effects on foundation species. The present work also contributes to the literature of sublethal effects that identifies systemic effects from cumulative small-scale stressors (Mopper et al. 1991, Feller 2002). Through cumulative boring damage, isopods may affect the performance, fitness, survivorship, and morphology of mangroves - all of which can alter the structure and function of this important ecosystem and the biota living therein. 
Acknowledgements. We thank C.P. Chen, Hsiao-Hang (Stacy) Tao, Joe Huang, and the rest of the Hsieh and Chen laboratories for logistical and field support. Ernie Estevez and anonymous reviewers greatly improved previous versions of this manuscript. Heejun Chang, Elise Granek, Gregory Ruiz, and Mark Sytsma provided helpful advice. The staff of the Summer Institute in Taiwan and Academia Sinica provided key logistical support. We are grateful for the funding provided by the National Science Foundation East Asia and South Pacific Summer Institute fellowship program in Taiwan (OISE-101514 to T.M.D.) and the Taiwan National Science Council (NSC-99-2911-I-007-014).

\section{LITERATURE CITED}

Anderson C, Lee SY (1995) Defoliation of the mangrove Avicennia marina in Hong Kong: cause and consequences. Biotropica 27:218-226

Benjamini Y, Hochberg Y (1995) Controlling the false discovery rate: a practical and powerful approach to multiple testing. J R Stat Soc B 57:289-300

Brooks RA, Bell S (2002) Mangrove response to attack by a root boring isopod: root repair versus architectural modification. Mar Ecol Prog Ser 231:85-90

> Cannicci S, Burrows D, Fratini S, Smith TJ III, Offenberg J, Dahdouh-Guebas F (2008) Faunal impact on vegetation structure and ecosystem function in mangrove forests: a review. Aquat Bot 89:186-200

Chapman S, Hart S, Cobb N (2003) Insect herbivory increases litter quality and decomposition: an extension of the acceleration hypothesis. Ecology 84:2867-2876

Chen TS, Lai GX, Xue ML (1996) Preliminary restoration results of Rhizophora stylosa. In: Peng GD (ed) Proceedings of Mangrove ecosystem conference. 29 December 1995, Taichung, Taiwan. Taiwan Endemic Species Research Institute, Nantou County, p 81-91

Ellison AM, Farnsworth EJ (1990) The ecology of Belizean mangrove-root fouling communities. I. Epibenthic fauna are barriers to isopod attack of red mangrove roots. J Exp Mar Biol Ecol 142:91-104

Estevez E, Simon J (1975) Systematics and ecology of Sphaeroma (Crustacea: Isopoda) in the mangrove habitats of Florida. In: Walsh G, Snedaker S, Teas H (eds) Proceedings of the international symposium of biology and management of mangroves. Institute of Food and Agricultural Sciences. University of Florida, Gainesville, FL, p 286-304

Feller IC (2002) The role of herbivory by wood-boring insects in mangrove ecosystems in Belize. Oikos 97:167-176

Feller IC, Mathis WN (1997) Primary herbivory by woodboring insects along an architectural gradient of Rhizophora mangle. Biotropica 29:440-451

Feller IC, McKee KL (1999) Small gap creation in Belizean mangrove forests by a wood-boring insect. Biotropica 31: $607-617$

Gill A, Tomlinson P (1977) Studies on the growth of red mangrove (Rhizophora mangle L.) 4. The adult root system. Biotropica 9:145-155

$>$ Hsueh ML, Lee HH (2000) Diversity and distribution of the mangrove forests in Taiwan. Wetlands Ecol Manage 8: 233-242

Kathiresan K (2003) How do mangrove forests induce sedimentation? Rev Biol Trop 51:355-359
Kathiresan K, Bingham B (2001) Biology of mangroves and mangrove ecosystems. Adv Mar Biol 40:81-251

Kensley B, Schotte M (1989) Guide to the marine isopod crustaceans of the Caribbean. Smithsonian Institution Press, Washington, DC

Kitaya Y, Yabuki K, Kiyota M, Tani A (2002) Gas exchange and oxygen concentration in pneumatophores and prop roots of four mangrove species. Trees (Berl) 16:155-158

Krauss K, Allen J, Cahoon D (2003) Differential rates of vertical accretion and elevation change among aerial root types in Micronesian mangrove forests. Estuar Coast Mar Sci 56:251-259

Kulman H (1971) Effects of insect defoliation on growth and mortality of trees. Annu Rev Entomol 16:289-324

Lightfoot D, Whitford W (1990) Phytophagous insects enhance nitrogen flux in a desert creosotebush community. Oecologia 82:18-25

Mattson W, Addy N (1975) Phytophagous insects as regulators of forest primary production. Science 190:515-522

Mopper S, Maschinski J, Cobb N, Whitham T (1991) A new look at habitat structure: consequences of herbivoremodified plant architecture. In: Bell SS, McCoy ED, Mushinsky HR (eds) Habitat structure: the physical arrangement of objects in space. Chapman \& Hall, New York, NY, p 260-280

Nagelkerken I, Blaber SJM, Bouillon S, Green P and others (2008) The habitat function of mangroves for terrestrial and marine fauna: a review. Aquat Bot 89:155-185

> Ozaki K, Kitamura S, Subiandoro E, Taketani A (1999) Life history of Aulacaspis marina Takagi and Williams (Hom., Coccoidea), a new pest of mangrove plantations in Indonesia, and its damage to mangrove seedlings. J Appl Entomol 123:281-284

Peng GD, Lai GX, Huang ZQ, Liu KY, Xue ML (1993) Restoration results of Rhizophora stylosa and Lumnitzera racemosa. Research program implementation results of Taiwan Endemic Species Research Institute. Project no. 3.7. Taiwan Endemic Species Research Institute, Nantou County

Perry D (1988) Effects of associated fauna on growth and productivity in the red mangrove. Ecology 69:1064-1075

Perry D, Brusca R (1989) Effects of the root-boring isopod Sphaeroma peruvianum on red mangrove forests. Mar Ecol Prog Ser 57:287-292

Piyakarnchana T (1981) Severe defoliation of Avicennia alba BL. by larvae of Cleora injectaria Walker. J Sci Soc Thailand 7:33-36

Primavera JH (1998) Mangroves as nurseries: shrimp populations in mangrove and non-mangrove habitats. Estuar Coast Mar Sci 46:457-464

Rehm A (1976) The effects of the wood-boring isopod Sphaeroma terebrans on the mangrove communities of Florida. Environ Conserv 3:47-57

Rehm A, Humm HJ (1973) Sphaeroma terebrans: a threat to the mangroves of Southwestern Florida. Science 182: 173-174

Reubens B, Poesen J, Danjon F, Geudens G, Muys B (2007) The role of fine and coarse roots in shallow slope stability and soil erosion control with a focus on root system architecture: a review. Trees (Berl) 21:385-402

Santhakumari V (1991) Destruction of mangrove vegetation by Sphaeroma terebrans along Kerala India coast. Fish Technol 28:29-32

Simberloff D, Brown BJ, Lowrie S (1978) Isopod and insect 
root borers may benefit Florida mangroves. Science 201: 630-632

Sousa WP, Quek SP, Mitchell BJ (2003) Regeneration of Rhizophora mangle in a Caribbean mangrove forest: interacting effects of canopy disturbance and a stem-boring beetle. Oecologia 137:436-445

Spenceley A (1977) The role of pneumatophores in sedimentary processes. Mar Geol 24:M31-M37

Svavarsson J, Osore MKW, Olafsson E (2002) Does the wood-borer Sphaeroma terebrans (Crustacea) shape the distribution of the mangrove Rhizophora mucronata? Ambio 31:574-579

Tomlinson PB (1986) The botany of mangroves. Cambridge

Editorial responsibility: Christine Paetzold, Oldendorf/Luhe, Germany
University Press, New York, NY

Wang HW (2012) National Important Wetland Conservation Action Plan: rehabilitating the hydrologic and ecological environment at Haomeiliao wetland and Budai Salt Pan Wetland (Part 2). Final report to Construction and Planning Agency, Ministry of Interior, Taiwan and Chiayi County Government. Construction and Planning Agency, Ministry of Interior, Taipei

Whitten A, Damanik S (1986) Mass defoliation of mangroves in Sumatra, Indonesia. Biotropica 18:176

Wier AM, Tattar TA, Klekowski EJ Jr (2000) Disease of red mangrove (Rhizophora mangle) in southwest Puerto Rico caused by Cytospora rhizophorae. Biotropica 32:299-306

Submitted: February 12, 2014; Accepted: September 12, 2014 Proofs received from author(s): November 22, 2014 